\title{
TEMPORAL AND SPATIAL VARIATION ON HEAVY METAL CONCENTRATIONS IN THE OYSTER Ostrea equestris ON THE NORTHERN COAST OF RIO DE JANEIRO STATE, BRAZIL
}

\author{
FERREIRA, A. G., MACHADO, A. L. S. and ZALMON, I. R. \\ Laboratório de Ciências Ambientais, Centro de Biociências e Biotecnologia, \\ Universidade Estadual do Norte Fluminense, Avenida Alberto Lamego, 2000, \\ Parque Califórnia, CEP 28013-602, Campos dos Goytacazes, RJ, Brazil \\ Correspondence to: Alexandre Gomes Ferreira, Laboratório de Ciências Ambientais, Centro de Biociências e \\ Biotecnologia, Universidade Estadual do Norte Fluminense, Avenida Alberto Lamego, 2000, \\ Parque Califórnia, CEP 28013-602, Campos dos Goytacazes, RJ, Brazil, e-mail: alexandre@uenf.br \\ Received December 16, 2002 - Accepted September 9, 2003 - Distributed February 28, 2005 \\ (With 3 figures)
}

\begin{abstract}
Heavy metal $(\mathrm{Cd}, \mathrm{Cr}, \mathrm{Cu}, \mathrm{Fe}, \mathrm{Mn}, \mathrm{Ni}, \mathrm{Pb}$, and $\mathrm{Zn})$ concentrations were determined by ICP-AES in Ostrea equestris from three beaches (Barra do Furado, Buena, and Ponta do Retiro) on the northern coast of Rio de Janeiro State. The average concentration was $0.8 \pm 0.18,0.4 \pm 0.21,58 \pm 25.6,249 \pm$ $52.3,11 \pm 1.31,0.55 \pm 0.16,0.13 \pm 0.11$, and $1131 \pm 321 \mu \mathrm{g} . \mathrm{g}^{-1}$ dry weight for $\mathrm{Cd}, \mathrm{Cr}, \mathrm{Cu}, \mathrm{Fe}, \mathrm{Mn}$, $\mathrm{Ni}, \mathrm{Pb}$, and $\mathrm{Zn}$ respectively. Significant spatial variation $(\mathrm{p}<0.05)$ between the samples areas occurred for $\mathrm{Cr}, \mathrm{Pb}$, and $\mathrm{Zn}$ with higher values in Barra do Furado; and for $\mathrm{Cu}$ in Ponta do Retiro. Significant temporal variations $(\mathrm{p}<0.05)$ were observed for all metals except $\mathrm{Cu}$. Temporal variability may be related to changes in the inputs of metals associated with suspended particles. Concentrations were similar to those found in areas under low pollution impact, except for $\mathrm{Zn}$, the high concentrations of which probably reflect the physiological characteristics of these organisms.
\end{abstract}

Key words: heavy metals, mollusks, spatial variation and temporal variation.

\section{RESUMO}

\section{Variação temporal e espacial da concentração de metais pesados na ostra Ostrea equestris na costa norte do Estado do Rio de Janeiro, Brasil}

Foram determinadas as concentrações de metais pesados $(\mathrm{Cd}, \mathrm{Cr}, \mathrm{Cu}, \mathrm{Fe}, \mathrm{Mn}, \mathrm{Ni}, \mathrm{Pb}$ e $\mathrm{Zn})$ na ostra Ostrea equestris em três praias (Barra do Furado, Buena e Ponta do Retiro) da costa norte do Estado do Rio de Janeiro utilizando-se ICP-AES. As concentrações médias foram $0,8 \pm 0,18 ; 0,4 \pm 0,21 ; 58 \pm$ 25,$6 ; 249 \pm 52,3 ; 11 \pm 1,31 ; 0,55 \pm 0,16 ; 0,13 \pm 0,11 ;$ e $1131 \pm 321 \mu \mathrm{g} \cdot \mathrm{g}^{-1}$ de peso seco para $\mathrm{Cd}, \mathrm{Cr}$, $\mathrm{Cu}, \mathrm{Fe}, \mathrm{Mn}, \mathrm{Ni}, \mathrm{Pb}$ e $\mathrm{Zn}$, respectivamente. Entre as áreas amostradas, houve variação espacial significativa $(\mathrm{p}<0,05)$ das concentrações de $\mathrm{Cr}, \mathrm{Pb}$ e $\mathrm{Zn}$ com maiores valores na Barra do Furado, e de $\mathrm{Cu}$ apenas em Ponta do Retiro. Foi observada variação temporal significativa $(\mathrm{p}<0,05)$ para todos os metais, exceto $\mathrm{Cu}$. Essa variabilidade provavelmente está associada a entradas de metais associados ao material particulado em suspensão. Os bivalves apresentaram concentrações similares àquelas encontradas em áreas com baixo impacto de contaminação por metais, exceto para $\mathrm{Zn}$, cujo acúmulo provavelmente está associado às características fisiológicas desses organismos.

Palavras-chave: metais pesados, moluscos, variação espacial e variação temporal. 


\section{INTRODUCTION}

Coastal waters are commonly an endpoint of toxic and environmentally harmful chemicals released by direct and indirect inputs to the coast (Moraes \& Silva, 1995; Nybakken, 1997). Trace elements are natural components of the hydrosphere although anthropogenic activity has altered their geochemical cycles, thus generating further cause for environmental concern.

In addition, heavy metal toxicity in aquatic organisms, in association with the long residence time within food chains, and the potential for human exposure makes it necessary to monitor heavy metal concentrations in aquatic organisms.

Marine organisms accumulate and concentrate heavy metals to high levels. Consequently, they are widely used as biomonitors indicating the extent of metal pollution in coastal waters (Lacerda et al., 1985; Szefer et al., 1998). One of the most successful examples of their use in biomonitoring is called the Mussel Watch Program (Cantillo, 1998).

The aim of this work is to determine $\mathrm{Cd}, \mathrm{Cr}$, $\mathrm{Cu}, \mathrm{Fe}, \mathrm{Mn}, \mathrm{Ni}, \mathrm{Pb}$, and $\mathrm{Zn}$ concentrations in the oyster Ostrea equestris collected on the northern coast of Rio de Janeiro State at three beaches: Barra do Furado (BF), Buena (B), and Ponta do Retiro (PR) (Fig. 1), so as to evaluate temporal and spatial variation of these metals concentrations and identify the critical elements at each beach sampled.

\section{MATERIAL AND METHODS}

Oysters with similar lengths $(4.0-6.0 \mathrm{~cm})$ were collected at the low-middle littoral of three beaches every 45 days approximately (from July 1998 to May 1999). The samples were washed with local seawater and transported in plastic bags to the laboratory. The soft tissues were removed from their shells, grouped $(\mathrm{n}=15)$, oven-dried at $60^{\circ} \mathrm{C}$, and ground to a fine powder with a porcelain pestle and mortar. Aliquots (approximately $1.00 \mathrm{~g}$ of dried tissue) were digested (triplicate) in concentrated $\mathrm{HNO}_{3}$, evaporated and redissolved in $0.5 \mathrm{~N} \mathrm{HNO}_{3}$ (PáezOsuna et al., 1995; Riget et al., 1997). The extracts were analyzed by atomic emission spectrophotometry with induced coupled plasma (ICP-AES).

Standard reference material was analyzed in order to estimate the accuracy of the digestion method (muscle tissue of Squalus acanthias - DORM
1) supplied by the Marine Analytical Chemistry Standards Programs (Canada). The heavy metal recovery rates were $84 \%(\mathrm{Cr}), 102 \%(\mathrm{Cu}), 99 \%(\mathrm{Fe})$, $87 \%(\mathrm{Mn}), 93 \%(\mathrm{Ni})$, and $88 \%(\mathrm{Zn})$.

The Mann-Whitney statistical analysis $(\mathrm{p}<$ 0.05 ) was applied to compare metal concentrations between the sampled areas. Kruskal-Wallis ( $\mathrm{p}<$ 0.05 ) variance analysis was used to compare the temporal variation of metal concentrations in each sampled area.

\section{RESULTS}

Metal concentrations remained on average within the variation commonly described in the literature for natural areas or areas slightly affected by metal pollutants (Table 1). This indicates that the contents of these elements in the oysters reflect the variations and natural availability for incorporation by marine bivalves on the northern coast of Rio de Janeiro State.

Among the analyzed metals, there were no significant differences $(p<0.05)$ among the beaches in the concentration of $\mathrm{Cd}, \mathrm{Fe}, \mathrm{Mn}$, and $\mathrm{Ni}$, suggesting similar bioavailabilities of these metals among the sampling sites (Fig. 2).

Concentrations of $\mathrm{Cd}, \mathrm{Ni}$, and $\mathrm{Pb}$ presented a significant temporal variation in all the sampling sites (Fig. 3). Despite these results, it is likely that such variability is associated to natural fluctuations of these concentrations, as the highest levels are below the values commonly cited in the literature for non-contaminated areas.

\section{DISCUSSION}

Only the $\mathrm{Zn}$ concentration, with average values of $162 \mu \mathrm{g} \cdot \mathrm{g}^{-1}$ wet weight, was above the maximum limit of tolerance (MLT) established for human consumption: $50 \mu \mathrm{g} \cdot \mathrm{g}^{-1}$ wet weight (Brazilian Ministry of Health, 1978, apud Lima, 1997). However, the MLT values shown do not correspond to those commonly cited in the literature (usually higher) for fish, even when they come from nonpolluted areas (Table 1). The well-known element $\mathrm{Zn}$, which easily accumulates in oysters, by far surpasses the MLT (Pfeiffer et al., 1985; Lima et al., 1986; Carvalho et al., 1993; Rabelo et al., 1998). Our results confirm this trend, showing the capacity of those organisms to metabolically control high $\mathrm{Zn}$ concentrations. 
Ke \& Wang (2001) noticed that Zn incorporation through feeding in Crassostrea rivularis and Saccostrea glomerata, contributed by more than $50 \%$ to the accumulation of this metal. These same authors show that the bivalve digestive process is divided into two phases: one extracellular, in which digestive enzymes act upon ingested particles, and a second one in which cells of the digestive diverticulum account for the intracellular degradation of ingested particles, with extremely efficient absorption of the final product. This partially explains the oyster's high capacity to assimilate metals like $\mathrm{Zn}$ and $\mathrm{Cu}$.

TABLE 1

Average concentrations of $\mathrm{Cd}, \mathrm{Cr}, \mathrm{Cu}, \mathrm{Fe}, \mathrm{Mn}, \mathrm{Ni}, \mathrm{Pb}$, and $\mathrm{Zn}\left(\mu \mathrm{g}^{-\mathrm{g}^{-1}}\right.$ dry weight) in oysters of non-impacted (a) and impacted (b) areas for heavy metals. $\mathrm{MC}=$ maximum concentration for human consumption in $\mu \mathrm{g} . \mathrm{g}^{-1}$ of wet weight (w.w.).

\begin{tabular}{|c|c|c|c|c|c|c|c|c|c|c|}
\hline Sampled area/Specie & Pollut. & Cd & $\mathrm{Cr}$ & $\mathrm{Cu}$ & $\mathbf{F e}$ & Mn & $\mathbf{N i}$ & $\mathbf{P b}$ & $\mathbf{Z n}$ & Reference \\
\hline Mexico/C. virginica & (b) & 4.1 & - & 326 & 949 & 38 & - & 8.8 & 628 & Vázquez et al., 1993 \\
\hline El Salvador/O. iridescens & (b) & $<1.2$ & 15.8 & 622 & - & - & 10.6 & $<1.2$ & 2040 & Michel \& Zengel, 1998 \\
\hline B. Sepetiba/C. brasiliana & (b) & 9.5 & 8.03 & - & 227 & - & - & - & 8881 & Lima et al., 1986 \\
\hline B. Ribeira/C. brasiliana & (a) & 3.2 & 5.1 & - & 314 & - & - & - & 1773 & Lima et al., 1986 \\
\hline B. Sepetiba/C. brasiliana & (b) & 8.5 & - & 24.5 & - & 30.1 & 18.1 & 13.5 & 9500 & Gomes et al., 1991 \\
\hline A. dos Reis/C. brasiliana & (a) & 1.7 & - & 227 & - & 30.5 & 25 & $<1.3$ & 2349 & Gomes et al., 1991 \\
\hline B. Guanabara/C. brasiliana & (b) & 0.4 & - & 148 & - & 35.8 & 3.4 & $<1.3$ & 1303 & Gomes et al., 1991 \\
\hline Mexico/C. iridescens & (a) & 1.5 & $<0.7$ & 2.4 & 109 & 11.5 & 2.1 & $<1.2$ & 500 & Páez-Osuna et al., 1995 \\
\hline P. Retiro/O. equestris & & $0.8 / 0.11$ & $0.3 / 0.04$ & $86 / 12.3$ & $300 / 42.9$ & $9.7 / 1.39$ & $0.7 / 0.1$ & $0.07 / 0.01$ & $1200 / 171.4$ & Present work, 1999 \\
\hline Buena/O. equestris & & $1.0 / 0.14$ & $0.3 / 0.04$ & $50 / 7.14$ & $200 / 28.6$ & $11 / 1.57$ & $0.5 / 0.07$ & $0.05 / 0.01$ & $800 / 114.3$ & Present work, 1999 \\
\hline B. Furado/O. equestris & & $0.6 / 0.09$ & $0.7 / 0.1$ & $39 / 5.57$ & $240 / 34.3$ & $12 / 1.71$ & $0.4 / 0.06$ & $0.25 / 0.04$ & $1400 / 200$ & Present work, 1999 \\
\hline MC (w.w.) & & 1 & 0.1 & 30 & - & - & - & 20 & 50 & Brazilian Federal Legislation, 1978 \\
\hline
\end{tabular}

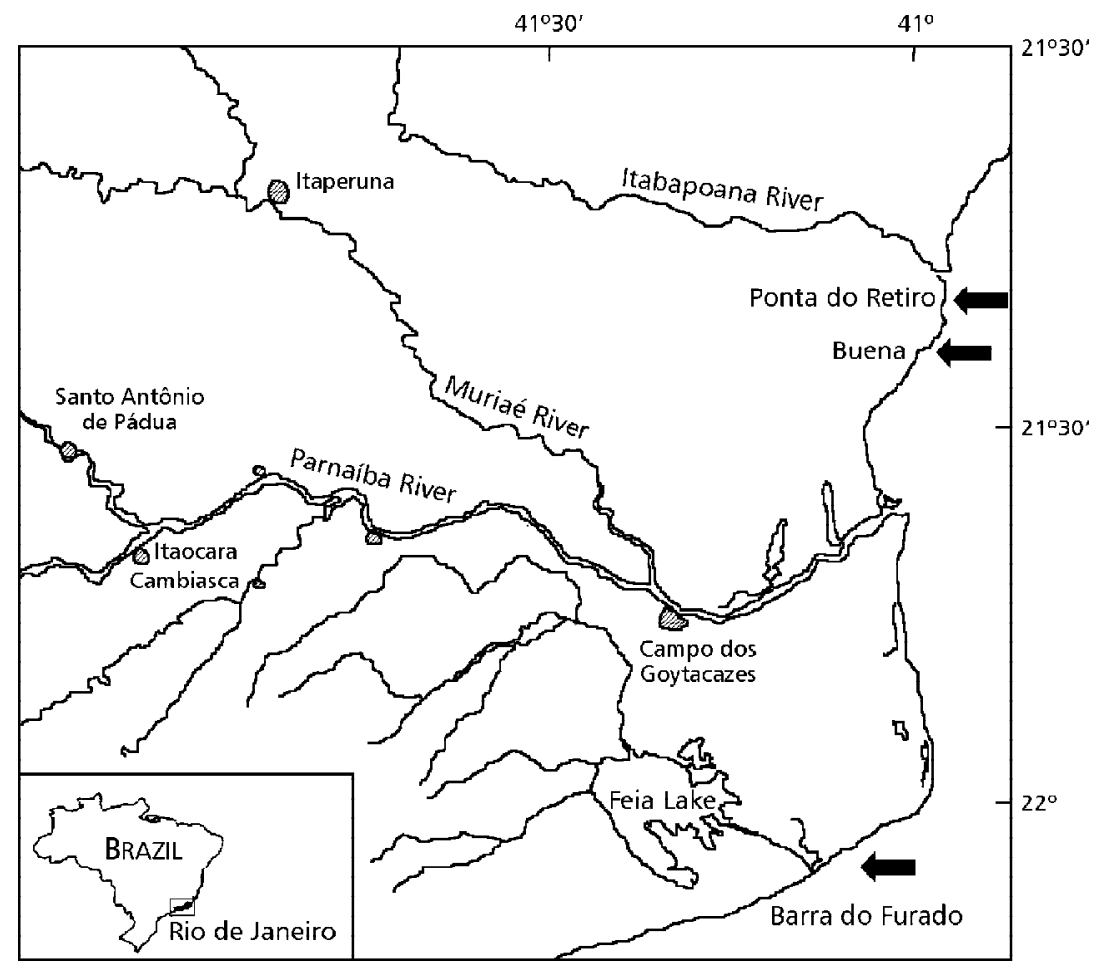

Fig. 1 - Northern coast of Rio de Janeiro State with the sampled sites (set points): Ponta do Retiro beach (21 $29^{\prime}$ S; $\left.40^{\circ} 59^{\prime} \mathrm{W}\right)$, Buena beach $\left(21^{\circ} 29^{\prime} \mathrm{S} ; 41^{\circ} \mathrm{W}\right)$, Barra do Furado beach $\left(22^{\circ} \mathrm{S} ; 41^{\circ} \mathrm{W}\right)$. 

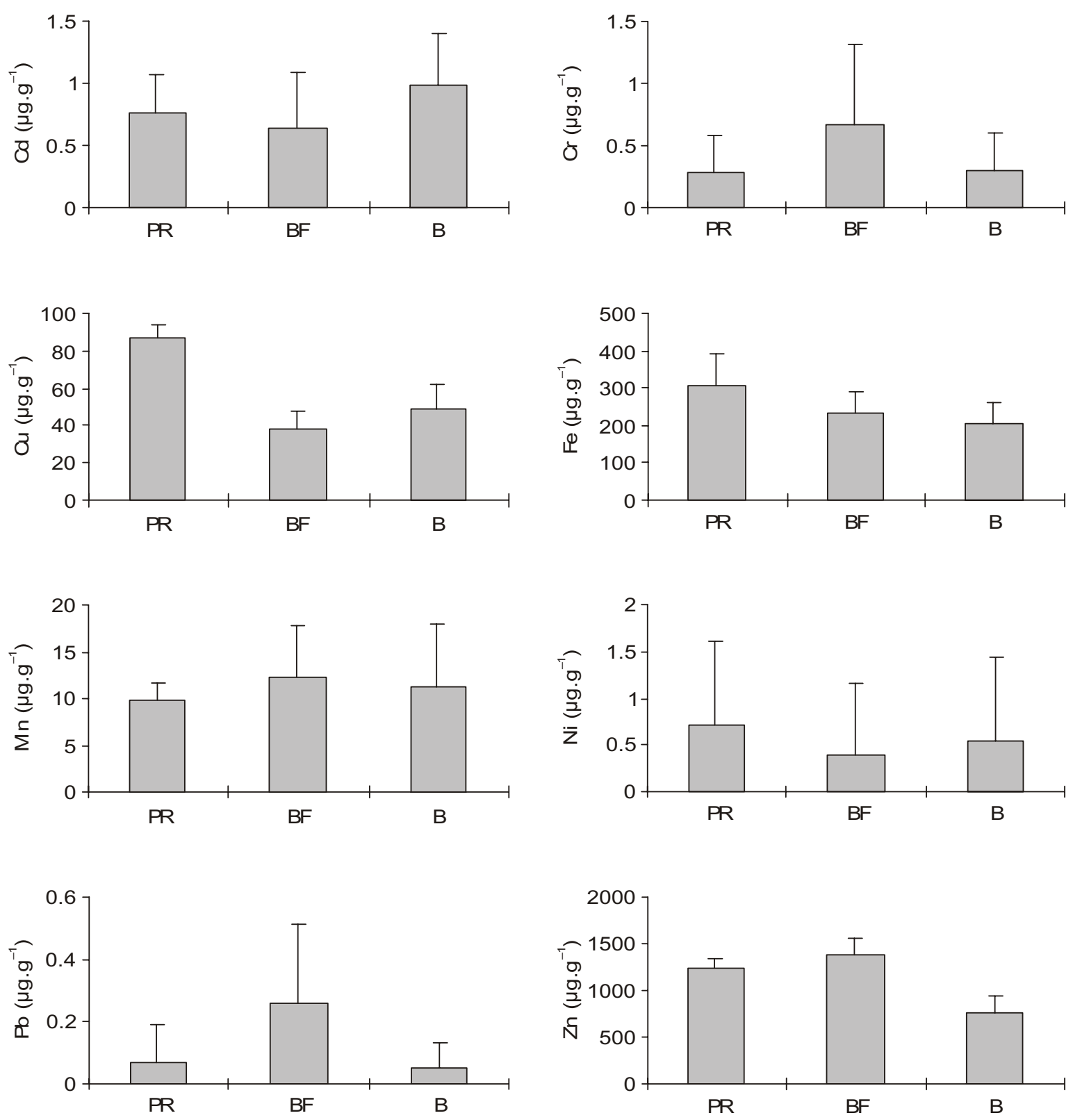

Fig. 2 - Average and standard deviation of $\mathrm{Cd}, \mathrm{Cr}, \mathrm{Cu}, \mathrm{Fe}, \mathrm{Mn}, \mathrm{Ni}, \mathrm{Pb}$, and $\mathrm{Zn}$ concentrations $\mu \mathrm{g} \cdot \mathrm{g}^{-1}$ (dry weight) in each sampled area $(\mathrm{PR}=$ Ponta do Retiro, $\mathrm{BR}=$ Barra do Furado; and $\mathrm{B}=$ Buena $)(\mathrm{N}=30)$.

Although Zn plays an important role in the composition of approximately 90 enzymes in animal metabolism (Bowen, 1979, apud Carvalho et al., 1993), mistakes in measurements affecting restrictions on the consumption of oysters may have been made.

When we compare the results for Ostrea equestris to the ones described for the mussel Perna perna in the same sampling sites (Ferreira, 2000), what is shown are different capacities to concentrate metals. The high capacity of P. perna to accumulate $\mathrm{Fe}$ and $\mathrm{Ni}$, and, in lower proportions, $\mathrm{Cr}$ and $\mathrm{Mn}$ was not observed for $O$. equestris in the present study. This result is related to the particular physiology of each organism with respect to the nature of each metal (Amiard et al., 1987). 

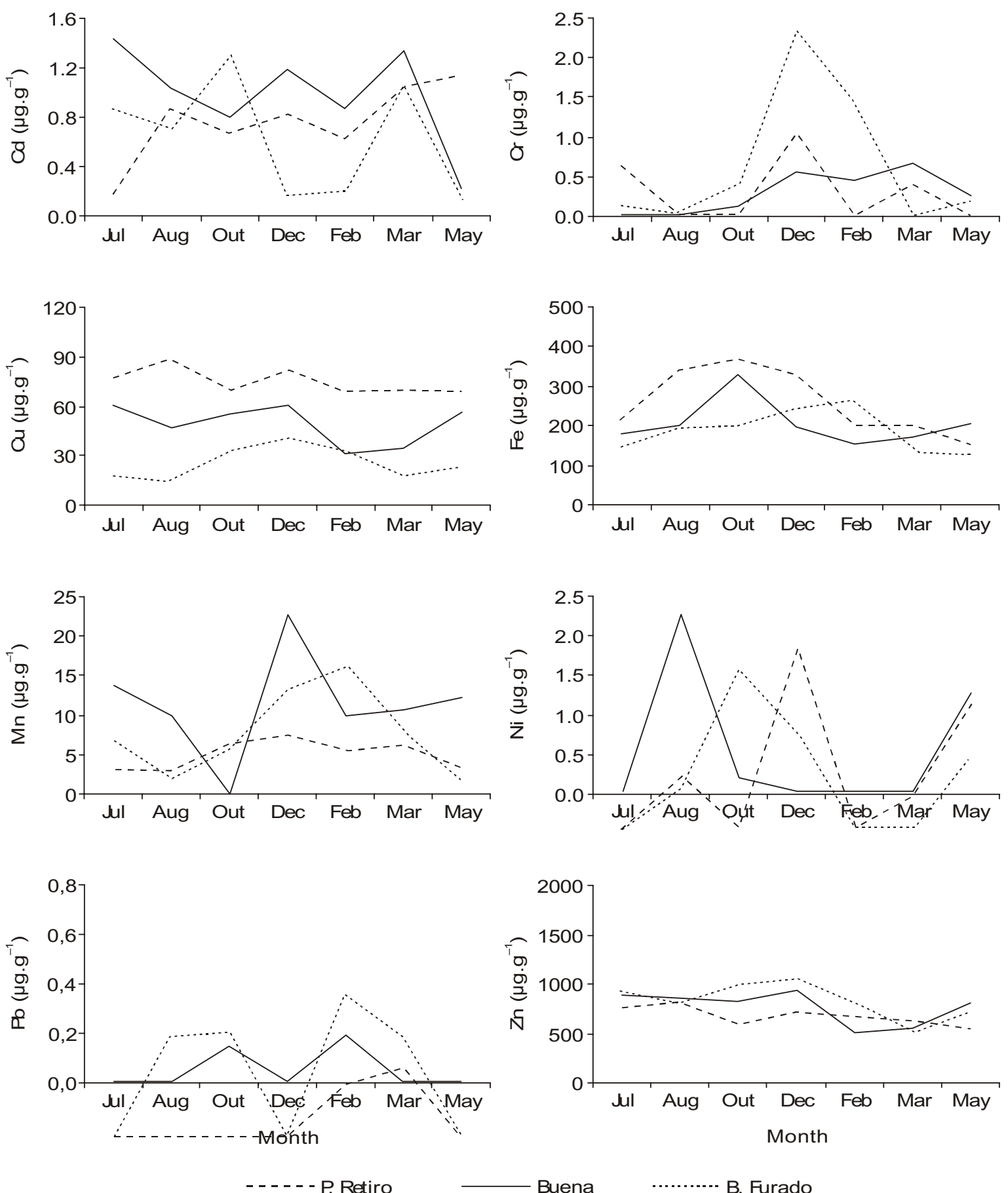

Buena

B. Furado

Fig. 3 - Temporal variation of $\mathrm{Cd}, \mathrm{Cr}, \mathrm{Cu}, \mathrm{Fe}, \mathrm{Mn}, \mathrm{Ni}, \mathrm{Pb}$, and $\mathrm{Zn}$ concentrations $\mu \mathrm{g} \cdot \mathrm{g}^{-1}$ (average in dry weight) in each sampled area (Ponta do Retiro, Barra do Furado, Buena). 
Opposite results were observed when comparing the concentration of $\mathrm{Cu}$ and $\mathrm{Zn}$ in P. perna and $O$. equestris. The latter showed a capacity at least 10 to 25 times higher to accumulate these metals, respectively. Other authors (Gomes et al., 1991; Carvalho et al., 1993; Michel \& Zengel, 1998) have described this characteristic. Differences in concentrations of $\mathrm{Cu}$ and $\mathrm{Zn}$ among mussels and oysters have been attributed to the presence of the respiratory pigment hemocyanin in oyster blood and its absence in mussels (Ke \& Wang, 2001). Zata (1984) showed that each functional unit of hemocyanin is capable of linking two $\mathrm{Cu}$ atoms and four of $\mathrm{Zn}$. These findings help to understand the oyster's high capacity to concentrate those metals.

\section{Spatial variation on heavy metal concentrations}

The $\mathrm{Cr}$ concentration varied significantly between Barra do Furado $\left(0.7 \mu \mathrm{g} . \mathrm{g}^{-1}\right)$ and the remaining beaches (average of $0.3 \mu \mathrm{g} . \mathrm{g}^{-1}$ in Ponta do Retiro and Buena), indicating a higher availability of this metal at the first beach. As there are apparently no sources of this metal in the local environment, these values can be related to natural inputs, coming from the Flechas channel, the only link between Feia lagoon and the sea, and flowing into Barra do Furado (Fig. 1).

Machado (1999) observed the same pattern when determining the $\mathrm{Cr}$ concentration in benthic marine algae at these beaches. Considering that marine algae are likely to accumulate metals in the dissolved fraction (Karez et al., 1994), the present results might indicate that this fraction is an important source of this element's incorporation by oysters.

A significant spatial difference $(\mathrm{p}<0.05)$ was recorded for $\mathrm{Cu}$ in $O$. equestris in Ponta do Retiro $\left(86 \mu \mathrm{g} . \mathrm{g}^{-1}\right)$ when compared to Buena $\left(50 \mu \mathrm{g} . \mathrm{g}^{-1}\right)$ and Barra do Furado $\left(39 \mu \mathrm{g} \cdot \mathrm{g}^{-1}\right)$. As the main source of this metal in coastal environments is associated to domestic sewage (Pfeiffer et al., 1985; Rezende \& Lacerda, 1986), the higher values of this metal at the first beach may indicate anthropogenic inputs of $\mathrm{Cu}$ from the Itabapoana river. Its estuary is about $12 \mathrm{~km}$ away from the sampling site and it carries urban waste, visible at the site (plastic material, decomposed organic garbage, etc.) through the coastal drift.

The concentration of $\mathrm{Zn}$ in $O$. equestris differed significantly $(\mathrm{p}<0.05)$ between Buena $\left(800 \mu \mathrm{g} \cdot \mathrm{g}^{-1}\right)$ and the other two beaches $\left(1200 \mu \mathrm{g} \cdot \mathrm{g}^{-1}\right.$ in Ponta do Retiro and $1400 \mu \mathrm{g} . \mathrm{g}^{-1}$ in Barra do Furado) (Fig. 2). Ferreira (2000) found higher concentrations of $\mathrm{Zn}$ in P. perna collected in Barra do Furado than in the ones in Ponta do Retiro and Buena. Higher $\mathrm{Zn}$ values at Ponta do Retiro, which is relatively close to Buena where lower concentrations were observed, reinforce results found by Lima et al. (1986) and Lima (1997). Both studies reported a wide range of concentration variation of this metal among individuals of the same population. On the other hand, as this is an essential metal involved in a wide variety of metabolic functions (Hamer, 1980; Páez-Osuna et al., 1995; Almeida et al., 1997) there may be a contribution of certain individual physiological variables (e.g., increase of gonadal maturation) and environmental variables (e.g., increase in suspended particulate-matter content), which possibly influence the bioaccumulation of this metal.

Ward et al. (1986) and Olivier et al. (2002), hypothesize the existence of an antagonism between the $\mathrm{Zn}$ accumulation in bivalve mussels to the detriment of $\mathrm{Cd}$ accumulation. This hypothesis is confirmed by the present results, in which we observed that on average, the highest $\mathrm{Zn}$ concentration $\left(1400 \mu \mathrm{g} . \mathrm{g}^{-1}\right)$ corresponded to the lowest Cd concentration $\left(0.6 \mu \mathrm{g} . \mathrm{g}^{-1}\right)$ in Barra do Furado. The same was true for the samples collected in Buena beach, where the lowest average $\mathrm{Zn}$ concentration $\left(800 \mu \mathrm{g} \cdot \mathrm{g}^{-1}\right)$ corresponded to the highest $\mathrm{Cd}$ values $\left(1.0 \mu \mathrm{g} \cdot \mathrm{g}^{-1}\right)$. This hypothesis would directly relate to the similar chemical behavior of those metals, both belonging to the same group in the periodic table.

A significant difference in the $\mathrm{Pb}$ concentration in O. equestris in Barra do Furado $\left(0.04 \mu \mathrm{g} . \mathrm{g}^{-1}\right)$ with that found in Buena and Ponta do Retiro (both with $\left.0.01 \mu \mathrm{g} . \mathrm{g}^{-1}\right)$ may be related to anthropogenic inputs at these beaches, although low concentrations have been recorded. They were inferior to those described in the literature for nonimpacted areas. Phillips et al. (1982) and Riget et al. (1997) reported that $\mathrm{Pb}$ is not significantly accumulated by marine biota, even when its concentration is high in abiotic compartments. Besides, the main input, caused by atmosphere deposition of this element into the marine environment, has been drastically reduced after the prohibition of this element in gasoline, which explains the observed low concentration. Páez-Osuna et al. (2002) observed a significant correlation between the concentration of this metal and policyclic aromatical hydrocarbons (PAHs) in oysters collected in Mexico. These authors suggest that the source of both might be the local small fishery boats, which are also common in Barra do Furado. 


\section{Temporal variation on heavy metal concentrations at Barra do Furado beach}

Significant temporal variations of all elements except $\mathrm{Cu}$ were observed at Barra do Furado beach. This result is in accordance with those obtained by Thompson et al. (1987) and Ringwood et al. (1998) who reported regulator mechanisms in oysters that are capable of maintaining organism homeostasis even during periods of intensive exposure to $\mathrm{Cu}$.

Increasing $\mathrm{Cr}, \mathrm{Fe}, \mathrm{Mn}, \mathrm{Ni}$, and $\mathrm{Zn}$ concentrations were shown from October 1998 to February 1999. We believe that such results are related to continental inputs together with a period of intensive rain, which could increase the fluvial input of these metals to the region. During the period from October to December 1998, the rain was on average more intense (average of $88 \mathrm{~mm}$ ) than during the three earlier months (average of $38 \mathrm{~mm}$ ) and the later ones (average of $66 \mathrm{~mm}$ ).

The waters of Campos plain drain mainly into the estuary in Barra do Furado. This region is characterized by soils with high levels of organic material, the origin of which is principally vegetal material in different stages of composition (CIDE, 1997), and possibly enriched by metals like Fe e Mn (Salomão, 1997). These flooded areas release metals from superficial drainage as well as suspended particulate material (SPM) into the Flechas channel, and from there to the estuary (Kremiling (1988) mentioned SPM as an important source of metals in estuaries).

Regarding $\mathrm{Pb}$, we observed two temporal peaks: from August to October 1998 and from February to March 1999. However, the high variation along the sampling period, in many cases with concentrations below the detection limits of the method used, makes the statistical significance of findings for $\mathrm{Pb}$ questionable. Another researcher (Ferreira, 2000) describes a similar pattern of accumulation in the mussel $P$. perna at this beach during the same sampling period.

The only element for which concentrations were lower during the period of more intensive rain was Cd. Ke \& Wang (2001) and Mouneyrac et al. (1998) reported that $\mathrm{Cd}$ incorporation by oysters is drastically reduced with the increase of salinity. This finding has been linked to an increase of the complexation of chloride ions with the metal. This phenomenon is more evident in estuaries, as is the case in Barra do Furado.

\section{Buena and Ponta do Retiro beaches}

In Ponta do Retiro, the concentrations of $\mathrm{Cd}$, $\mathrm{Ni}$, and $\mathrm{Pb}$ varied significantly along the sampling period. No correlations were observed in the concentration of any of the metal elements at this beach. The $\mathrm{Cu}$ concentration remained constant throughout the sampling period.

Olivier et al. (2002) observed that temporal variation in the Cd concentrations in Saccostrea commercialis resulted from the dry weight of the individuals. The authors observed assert that $\mathrm{Cd}$ concentration tends to diminish with the increase of dry weight, thus a dilution effect occurs as the organism grows. In the present study, the previous selection of the size of the individuals collected (same size range) led to a decrease in the effect of size on heavy metal accumulations. However, belonging to the same size range does not necessarily imply that individuals are of the same age and weight. As they assume the irregular shape of the substrate to which they are attached, individuals can grow along a different axis from the longitudinal growing pattern expected. They assume, in this way, the internal shape of the shell, with enough space to develop and, thus, their true size is not obvious. This pattern has not been observed in Barra do Furado, whose substrate is formed exclusively by flat-surfaced granite rocks.

In Buena there was a significant temporal variation in the $\mathrm{Cd}, \mathrm{Fe}, \mathrm{Mn}, \mathrm{Ni}, \mathrm{Pb}$, and $\mathrm{Zn}$ concentrations. According to Haynes \& Toohey (1998), seasonal differences in the metal concentrations in mussels from nonimpacted environments are usually related to physicochemical variations of the water (which can alter metal bioavailability) and/or the feeding rates of the organism. Bryan (1993) mentions that the temporal variations in metal concentrations in the bivalves Pecten maximus and Chlamys opercularis are related to variations in local phytoplankton productivity. His observations are reinforced by the fact that an increase in phytoplankton productivity implies an increase in bivalve nutritional status, which in turn leads to an increase in metal concentration in organisms observed. Olivier et al. (2002) described similar results for the oyster Saccostrea commercialis.

Phillips (1979) related an increase in $\mathrm{Zn}$ concentration in bivalves to the incorporation occurring in summer of this metal by the plankton community. Evidence of seasonality was not observed in our study because of the ill-defined seasons in tropical regions. 
The Fe concentration varied significantly along the period in Buena, reaching its highest value in October 1998 (328 $\left.\mu \mathrm{g} \cdot \mathrm{g}^{-1}\right)$. In the same period, the highest concentrations were observed in Ponta do Retiro $\left(417 \mu \mathrm{g} . \mathrm{g}^{-1}\right)$, indicating a common origin of this metal in both beaches (probably the Itabapoana river, whose estuary is close to both sampling sites).

In Buena the $\mathrm{Mn}$ concentration varied significantly through time. This variation was different from that observed in Ponta do Retiro. These results make evident the complexity of the dynamic of heavy metals in marine environments. Different factors, whether biological (e.g., size, gonodal stage, filtration rate) or not (e.g., physicochemical characteristics of the water, sediment flux) can determine metal bioavailability in the environment.

The analysis of the suspended particulate material (SPM) mentioned as a source of several metals for the marine environment (Pfeiffer, 1980; Páez-Osuna et al., 1995; De Gregori et al., 1996) could better clarify the results observed at the beaches on the São Francisco do Itabapoana coast, since the Itabapoana river is the main exporter of this component. A more detailed analysis of metal contents in the SFM could provide clearer information. Furthermore, it should be taken into account that: (1) the drainage basin of this river is different from Feia lagoon regarding its hydrographical composition; (2) different pluvial indices in these locations could signify different loads of metals recently discharged into the sea and, consequently, their incorporation into the biota.

\section{CONCLUSION}

Ponta do Retiro, Buena, and Barra do Furado beaches can be classified as free from contamination by $\mathrm{Cd}, \mathrm{Cr}, \mathrm{Cu}, \mathrm{Fe}, \mathrm{Mn}, \mathrm{Ni}$, and $\mathrm{Pb}$.

The $\mathrm{Zn}$ concentration in O. equestris showed contents surpassing the maximum limit allowed for human consumption by the Brazilian Ministry of Health, which warrants a detailed investigation of the origin of this substance with respect to these organisms.

There were no significant differences in the $\mathrm{Cd}$, $\mathrm{Fe}, \mathrm{Mn}$, and $\mathrm{Ni}$ concentrations among the studied beaches. As for the remaining metals, the variations observed are probably related to anthropogenic input (e.g., sewage as well as pollution caused by small fishery boats active in the harbor) and/or fluvial input.
Regarding temporal variation in Barra do Furado, increases were observed in $\mathrm{Cr}, \mathrm{Fe}, \mathrm{Mn}$, and $\mathrm{Zn}$ concentrations in the samples collected in December 1998, a rainy period, suggesting possibly similar origins of these metals, e.g., suspended particulate material.

In Ponta do Retiro and Buena, no similar trend was detected of metal accumulation in specific months. This shows that the dynamic of these elements at those beaches needs additional studies so as to identify the sources, e.g., the Itabapoana river, ultimately resulting in their incorporation in the biota.

Considering the variations in the discharges, both in the lower part of the Itabapoana river and in the Flechas channel, which are exporters of suspended particulate material and, therefore, potential sources of metals at the studied beaches, more detailed studies, including collection of bivalves at shorter time intervals, could provide additional information about the influence of heavy metals affecting these areas.

Special attention should be given to the organisms collected at Ponta do Retiro and Buena. Since their shape is determined by the substract to which they are attached, their weight as well as size can be considered a limiting factor with respect to heavy metal accumulation.

We recommend the use of young individuals of Ostrea equestris for biomonitoring of $\mathrm{Cd}, \mathrm{Cu}$, and $\mathrm{Zn}$ at Ponta do Retiro, Buena, and Barra do Furado, as the species, besides showing a relative capacity to concentrate such metals, has a suitable size range, is widely distributed, and presents great population density in the majority of the stone reefs.

Acknowledgements - The authors thank Dr. Carlos Veiga de Carvalho for suggestions and comments during manuscript revision. This work has been supported by Conselho Nacional de Desenvolvimento Científico e Tecnológico (CNPq) and Fundação Estadual do Norte Fluminense (FENORTE).

\section{REFERENCES}

ALMEIDA, E. A., MEDEIROS, I. D., VENTURA, E. C., MEZZARI, M. P. \& BAINY, A. C. D., 1997, Análise de biomarcadores bioquímicos em mexilhões Perna perna de diferentes regiões do estado de Santa Catarina. An. 5o Enc. Brasil. Ecotox., Itajaí, SC, 25p.

AMIARD, J. C., AMIARD-TRIQUET, C., BERTHET, B. \& METAYER, C., 1987, Comparative study of the patterns of bioacumulation of essential $(\mathrm{Cu}, \mathrm{Zn})$ and nonessential $(\mathrm{cd}, \mathrm{pb})$ trace metals in various estuarine and coastal organisms. J. Exp. Mar. Ecol., 106: 73-89. 
BRYAN, G. W., 1993, The occurrence of seasonal variations of trace metals in Pecten maximus and Mytilus edulis L. J. Mar. Biol. Assoc., 53: 145-166.

CANTILLO, A. Y., 1998, Comparison of results of mussel watch programs of the United States and France witch wordwide Mussel Watch Studies. Mar. Pollut. Bullet., 36(9): 712-717.

CARVALHO, C. E. V., LACERDA, L. D. \& GOMES, M. P., 1993, Metais pesados na biota bêntica da Baía de Sepetiba e Angra dos Reis, RJ. Acta Limno. Brasil., 6: 222-229.

CIDE, 1997, Centro de Informação de Dados do Rio de Janeiro. Estado do Rio de Janeiro. Território, Rio de Janeiro, Relatório, $80 \mathrm{p}$.

DE GREGORI, I., PINOCHET, H., GRAS, N. \& MUNOZ, L., 1996 , Variability of cadmium, copper and zinc levels in molluscs and associated sediments from Chile. Environ. Pollut., 92(3): 359-368.

FERREIRA, A. G., 2000, Metais pesados em moluscos bivalves no litoral norte do Rio de Janeiro. Dissertação de Mestrado, Universidade Estadual do Norte Fluminense, Laboratório de Ciências Ambientais.

GOMES, M. P., CARVALHO, C. E. V. \& LACERDA, L. D., 1991, Monitores biológicos de metais pesados no litoral do Estado do Rio de Janeiro. An. Sem. Reg. Ecol., São Carlos, 6: 319-329.

HAMER, D. H., 1980, Metallothionein. Ann. Rev. Biochem., 55: 913-951.

HAYNES, D. \& TOOHEY, D., 1998, The use of transplanted, cultered mussels (Mytilus edulis) to monitor pollutants along the ninety Mile Beach, Victoria, Australia III. Heavy Metals. Mar. Pollut. Bull., 36(5): 396-399.

KAREZ, C. S., AMADO-FILHO, G. M., MOLL, D. M. \& PFEIFFER, W. C., 1994, Concentração de metais em algas marinhas bentônicas de três regiões do Estado do Rio de Janeiro. Na. Acad. Brás. Ci., 66(2): 205-211.

KE, C. \& WANG, W., 2001, Bioaccumulation of Cd, Se and $\mathrm{Zn}$ in an Estuarine Oyster (Crassostrea rivularis) and a Coastal Oyster (Saccostrea glomerata). Aquatic Toxicology, 56: $33-51$.

KREMILING, K., 1988, Metal cycles in the coastal environments. In: W. Seeliger, L. D. Lacerda \& S. R. Patchineelam, Metals in coastal environments of Latin America. Berlin Heidelberg, Spring-Verlag, New York, pp. 198-214.

LACERDA, L. D., TEIXEIRA, V. I. \& GUIMARÃES, V. R. D., 1985, Seasonal variation of heavy metals in seaweeds from Conceição de Jacareí, Brasil. Bot. Mar., 49(3): 847849.

LIMA, N. R. W., LACERDA, L. D., PFEIFFER, W. C. \& FISZMAN, M., 1986, Temporal and spatial variability in $\mathrm{Zn}, \mathrm{Cr}, \mathrm{Cd}$, and $\mathrm{Fe}$ concentrations in oyster tissues (Crassostrea rhyzophorae, Lamarck, 1819) from Sepetiba Bay, Brazil. Environ. Tech. Let., 7: 453-460.

LIMA, E. F. A., 1997, Determinação de cádmio, cromo, cobre e zinco em mexilhões Perna perna (Llnné, 1758) do litoral do Estado do Rio de Janeiro. Dissertação de Mestrado, Depto. de Química, PUC/RJ, 151p.
MACHADO, A. L. S., 1999, Distribuição de metais pesados em macroalgas marinhas bentônicas no litoral norte do Estado do Rio de Janeiro. Monografia, Ciências Ambientais, UENF, $51 \mathrm{p}$.

MICHEL, J. \& ZENGEL, S., 1998, Monitoring of oyster and sediments in Acajutla, El Salvador. Mar. Pollut. Bull., 36(4): 256-266.

MORAES, R. B. C. \& SILVA, M. L. P., 1995, Toxicidade do zinco ao mexilhão Perna perna (Linné, 1758). Arq. Biol Tecnol., 38(2): 541-547.

MOUNEYRAC, C., AMIARD, J. C. \& AMIARD-TRIQUET, C., 1998, Effects of natural factors (salinity and body weight) on cadmium, cooper, zinc and metallothionein-like protein levels in resident populations of oysters Crossostrea gigas from a polluted estuary. Marine Ecology Progress Series., 162: 125-135.

NYBAKKEN, J. W., 1997, Marine biology: an ecological approach. Addison Wesley Educational Publishers Inc., $4^{\text {th }}$ ed., 11: 433-440.

OLIVIER, F., RIDD, M. \& KLUMPP, D., 2002, The use of transplanted cultured tropical oysters (Saccostrea commercialis) to monitor Cd levels in North Queensland Coastal waters (Australia). Mar. Pollut. Bull., 44: 10511062.

PÁEZ-OSUNA, P., FRIAS-ESPERICUETA, M. G. \& OSUNALÓPEZ, J. I., 1995, Trace metal concentrations in relation to season and gonadal maturation in the oyster Crassostrea iridescens. Mar. Environ. Res., 40(1): 19-31.

PÁEZ-OSUNA, F., RUIZ-FERNANDEZ, A. C., BOTELLO, A. V., PONCE-VÉLEZ, G., OSUNA-LÓPEZ, J. I., FRIASESPERICUETA, M. G., LÓPEZ-LÓPEZ, G. \& ZAZUETAPADILLA, H. M., 2002, Concentrations of selected trace metals $(\mathrm{Cu}, \mathrm{Pb}, \mathrm{Zn})$, organochlorines (PCB's, $\mathrm{HCB})$ and total PAHs in mangrove oysters from the Pacific Coast Mexico: an overview. Marine Pollution Bulletin. Article in press.

PFEIFFER, W. C., 1980, Trânsito do cromo em ecossistemas aquáticos. I Seminário sobre Poluição por Metais Pesados. SEMA, Brasília, Distrito Federal, pp. 29-37.

PFEIFFER, W. C., LACERDA, L. D., FISZMAN, M. \& LIMA, N. R. W., 1985, Metais pesados no pescado da Baía de Sepetiba, Estado do Rio de Janeiro. Ciência e Cultura, 37(2): 297-302.

PHILLIPS, D. J. H., 1979, Trace metals in the common mussel Myttilus edulis, and in the alga Fucus vesiculosus from the region of the Sound (Öresund). Environ. Pollut., 18: 31-43.

PHILliPS, D. J. H., THOMPSON, G. B., GABUJI, K. M. \& HO, C. T., 1982, Trace metals of toxicological significance to man in Hong-Kong seafood. Environ. Pollut. Ser. B., 3: 27-45.

RABELO, M. F., AMADO-FILHO, G. M., CORREA JR., J. D., BASTOS, W. R. \& PFEIFFER, W. C., 1998, Bioindicators of heavy metal contamination in the Sepetiba bay, Rio de Janeiro. An. 5., Enc. Brasil. Ecotox., Itajaí, SC.

REZENDE, C. E. \& LACERDA, L. D., 1986, Metais pesados em mexilhões Perna perna no litoral do Estado do Rio de Janeiro. Rev. Brasil. Biol., 46: 239-247. 
RIGET, F., JOHANSEN, P. \& ASMUND, G., 1997, Uptake and release of lead and zinc by blue mussels. Experience from transplantation experiments in Greenland. Mar. Pollut. Bull., 34(10): 805-815.

RINGWOOD, A. D., CONNERS, D. E. \& DINOVO, A., 1998, The effects of copper exposures on cellular responses in oysters. Mar. Environ. Res., 46(1-5): 591-595.

SALOMÃO, M. S. M. B., 1997, Dinâmica do material particulado em suspensão e de metais pesados na porção inferior do rio Paraiba do Sul. Monografia, Laboratório de Ciências Ambientais, UENF, Campos dos Goytacazes, RJ.

SZEFER, P., GELDON, J., ALI, A. A., PÁEZ-OSUNA, F., RUIZFERNANDES, A. C. \& GALVAN, S. R. G., 1998, Distribution and association of trace metals in soft tissue and byssus of Mitella strigata and other benthal organisms from Mazatlan Harbour, Mangrove lagoon of the Northwest Coast of Mexico. Environ. Inter., 24(3): 359-374.
THOMPSON, M. F., SAROJINE, R. \& NAGABHUSHANAM, R., 1987, Biology of benthic marine organisms. Techniques and methods as applied to the Indian Ocean. Balkema/ Rotterdam, pp. 96-109.

VÁZQUEZ, G. F., SANCHEZ, G. M. \& VIRENDER, K. S., 1993, Trace metals in the oyster Crassostrea virginica of the Terminos lagoon, Campeche, Mexico. Mar. Pollut. Bull., 26(7): 398-399.

WARD, T. J., CORRELL, R. L. \& ANDERSON, R. B., 1986, Distribution of cadmium, lead and zinc amongst the marine sediments, seagrasses and fauna and the selection of sentinel accumulators, near a lead smelter in South Australia. Marine Pollution Bulletin., 17: 567-585.

ZATA, P., 1984, Zinc transport in the Haemolynph of Carcinus maenas (Crustacea - Decapoda). Journal of the Marine Biological Association, United Kingdom, 84: 801-807. 